\title{
Fabrication of ZnO and ZnO:Sb Nanoparticles for Gas Sensor Applications
}

\author{
A. B. Kashyout, ${ }^{1}$ H. M. A. Soliman, ${ }^{1}$ H. Shokry Hassan, ${ }^{1}$ and A. M. Abousehly ${ }^{2}$ \\ ${ }^{1}$ Advanced Technology and New Materials Research Institute, Mubarak City for Scientific Research and Technology Applications \\ (MuCSAT), New Borg El-Arab City, Alexandria 21934, Egypt \\ ${ }^{2}$ Physics Department, Faculty of Science, Al-Azhar University, Al-Azhar uni Street, 71524 Assiut, Egypt
}

Correspondence should be addressed to A. B. Kashyout, hady8@yahoo.com

Received 15 November 2009; Accepted 31 August 2010

Academic Editor: P. Panine

Copyright ( 2010 A. B. Kashyout et al. This is an open access article distributed under the Creative Commons Attribution License, which permits unrestricted use, distribution, and reproduction in any medium, provided the original work is properly cited.

\begin{abstract}
$\mathrm{ZnO}$ and $\mathrm{Sb}$-doped $\mathrm{ZnO}$ nanoparticles were successfully prepared using sol-gel technique. Different concentrations of triethanolamine (TEA) were utilized as the preparation procedure to act as complexing agent that enhances the doping probability of the formed Sb-doped $\mathrm{ZnO}$ nanopowder. Thick films of the prepared nanopowders were fabricated with spinner coating. Morphological characteristics, phase structure, chemical composition, thermal stability, and optical properties of the prepared nanopowders were measured and analyzed. The average crystallite size of $\mathrm{ZnO}$ and $\mathrm{ZnO}: \mathrm{Sb}$ powders ranged between 19-28 nm according to the XRD calculations and TEM observations. The gas sensitivity of the homemade devices based on Sb-doped $\mathrm{ZnO}$ nanoparticles towards $\mathrm{O}_{2}$ and $\mathrm{CO}_{2}$ gases as a function of temperature was measured and compared with undoped $\mathrm{ZnO}$ films. The gas sensitivity of the films was greatly improved after doping with $\mathrm{Sb}$ and reached its maximum value of $\sim 86 \%$ for $\mathrm{O}_{2}$ gas at 93:7 wt $\%$ of $\mathrm{Zn}: \mathrm{Sb}$.
\end{abstract}

\section{Introduction}

Recently, there is a great need for the production of low cost transparent conducting films (e.g., $\mathrm{ZnO}, \mathrm{SnO}_{2}, \mathrm{In}_{2} \mathrm{O}_{3}$, and $\left.\mathrm{Cd}_{2} \mathrm{SnO}_{4}\right)$ [1-3] due to their applications in various energy efficient disciplines such as window layer in heterojunction solar cells, dye sensitized solar cells, heat mirrors, piezoelectric devices, multilayer photo thermal conversion systems, thin film transistor (TFT) and solid state gas sensors [4]. Metal oxide gas sensing films have been widely used due to their excellent properties such as small size, low cost, high sensitivity, fast response, and recovery speed. Enhancing the selectivity/sensitivity and improving the stability of the prepared oxides are urgent demands [5]. $\mathrm{ZnO}$ is an oxide of group II metallic zinc [6] that exists between semiconductors and ionic materials, which gives $\mathrm{ZnO}$ the electrical amphoteric property as $\mathrm{n}$-type semiconductor in most preparation procedures, although p-type conductivity was also reported under certain conditions $[7,8] . \mathrm{ZnO}$ is a very interesting material due to its high transmittance in the visible region and high chemical/thermal/mechanical stability [9]. The great advantage of using $\mathrm{ZnO}$ films in transparent electronic devices refer to the possibility of manufacturing high quality and transparent polycrystalline zinc oxide films at room temperature [10]. Several techniques have also been stated to grow doped and nondoped $\mathrm{ZnO}$ films as vapor condensation, thermal evaporation, spray pyrolysis, magnetron sputtering, metal organic chemical vapor deposition, and sol-gel among others [11-15]. However, most of these techniques need high temperature in order to get high quality polycrystalline materials. Antimony doped $\mathrm{ZnO}$ was prepared by mixing $\alpha$ $\mathrm{Sb}_{2} \mathrm{O}_{3}$ at high temperatures up to $1200^{\circ} \mathrm{C}$ [16]. Also, $\mathrm{ZnO}: \mathrm{Sb}$ was synthesized by vapor condensation route using $\mathrm{Zn}$ and $\mathrm{Zn}-\mathrm{Sb}$ alloy with different molar ratios [17]. Gas sensitivity towards some volatile organic compounds was evaluated within the produced $\mathrm{ZnO}: \mathrm{Sb}$ [17]. In this work, sol-gel route was used to prepare $\mathrm{ZnO}$ and $\mathrm{ZnO}: \mathrm{Sb}$ nanoparticles, then spinner coating technique was also used to prepare thick films for gas sensor devices. The effect of triethanolamine (TEA) on the properties of the $\mathrm{ZnO}$ nanoparticles was investigated. Different $\mathrm{Sb}$ doping ratios were incorporated 
into the $\mathrm{ZnO}$ matrix and their effects on different materials properties and gas sensing sensitivity were also studied.

\section{Experimental Details}

2.1. Preparation of $\mathrm{ZnO} / \mathrm{Sb}$-Doped $\mathrm{ZnO}$ Nanopowders and Films Fabrication. The $\mathrm{ZnO}$ nanopowders were prepared via sol-gel route [1] by mixing $0.1 \mathrm{M}$ aqueous solution of zinc nitrate monohydrate with different concentrations of TEA $(0.1,0.2,0.3,0.4$, and $0.5 \mathrm{M})$. In case of preparing 3, 5, 7 , and $10 \mathrm{wt} \% \mathrm{Sb}$-doped $\mathrm{ZnO}$; an equivalent amount of antimony trichloride was added to the mixture of zinc nitrate monohydrate and TEA. Then the resulting solutions were aged at $100^{\circ} \mathrm{C}$ for 24 hours. The obtained powders were washed with distilled water to remove any residual salts, centrifuged at $6000 \mathrm{rpm}$ for 30 minutes and finally dried at $30^{\circ} \mathrm{C}$. The colloidal solution was obtained by mixing the $\mathrm{ZnO}$ nanopowder with ethanol and vigorously stirred and left overnight to form homogeneous suspension of $20 \mathrm{wt} \%$ $\mathrm{ZnO}$. The suspension was applied onto the substrate by wafer spinner machine (Model Polos300 AWS) at $100 \mathrm{rpm}$ for 2 minutes or according to the desired thickness. The film was then allowed to dry in air for 15 minutes and sintered in airflow at $400^{\circ} \mathrm{C}$ for 5 minutes.

\subsection{Preparation of Solid State Semiconductor Gas Sensors.} The glass substrates were ultrasonically cleaned in acetone for 15 minutes, then rinsed several times with deionized water. The heater (platinum heater) was deposited by a sputtering machine (Turbo Sputtering RF \& DC Power Supplies Deposition System Model Hummer 8.1), $(P=100 \mathrm{~W}$ RF, $t=$ 2 minutes). Then, the suspension of metal oxide ( $\mathrm{ZnO}$ or Sbdoped $\mathrm{ZnO}$ ) was applied onto the substrate by wafer spinner machine (100 rpm, 2 minutes), then the film was allowed to dry in air and this was repeated for several times to achieve the desired thickness. Finally Pt contact was deposited $(P=$ $100 \mathrm{~W} \mathrm{RF}, t=2$ minutes).

2.3. Characterization of $\mathrm{ZnO}$ and $\mathrm{Sb}$-Doped $\mathrm{ZnO}$ Nanoparticles. X-ray diffraction patterns of the nanopowders were obtained using Schimadzu 7000 Diffractometer operating with $\mathrm{Cu} \mathrm{K} \alpha$ radiation $(\lambda=0.15406 \mathrm{~nm})$ generated at $30 \mathrm{kV}$ and $30 \mathrm{~mA}$ with scan rate of $2^{\circ} \mathrm{min}^{-1}$ for $2 \theta$ values between 20 and 80 degrees. Chemical composition of the Sb-doped $\mathrm{ZnO}$ nanoparticles was performed with an energy dispersive X-Ray Analysis (EDS) analyzer combined with scanning electron microscope (JEOL JSM 6360LA, Japan). ZnO:Sb nanoparticles micrographs for gas sensor consist of $\mathrm{ZnO}$ film, heater and the two Pt electrodes were investigated with SEM. The morphologies and size of $\mathrm{ZnO}$ and Sb-doped $\mathrm{ZnO}$ nanoparticles were obtained from TEM (JEOL JEM 1230, Japan) measurements. The FTIR spectrums of the prepared $\mathrm{ZnO}$ and $\mathrm{Sb}$-doped $\mathrm{ZnO}$ with 5, $10 \mathrm{wt} \%$ of $\mathrm{Sb}$ were measured using Shimadzu FTIR-8400 S, Japan over the wave length range $400-4000 \mathrm{~cm}^{-1}$. The thermal stability of $\mathrm{ZnO}$ prepared using different percentages of (TEA) was evaluated by Thermogravimetric analysis (TGA) using Thermogravimetric Analyzer (Shimadzu TGA -50 H, Japan).
TABLE 1: Variation of $\mathrm{pH}$ with reaction efficiency as a result of increasing TEA concentration.

\begin{tabular}{lccc}
\hline $\begin{array}{l}\text { TEA } \\
\text { concentration } \\
(\mathrm{mol} / \mathrm{l})\end{array}$ & $\begin{array}{c}\mathrm{Zn}\left(\mathrm{NO}_{3}\right)_{2} \cdot \begin{array}{l}\mathrm{H}_{2} \mathrm{O} \text { concentration } \\
(\mathrm{mol} / \mathrm{l})\end{array} \\
\mathrm{n}\end{array}$ & $\mathrm{pH}$ & $\begin{array}{c}\mathrm{ZnO} \text { yield } \\
\%\end{array}$ \\
\hline 0 & 0.1 & 3.5 & - \\
0.1 & 0.1 & 6.35 & 52 \\
0.2 & 0.1 & 6.71 & 64 \\
0.3 & 0.1 & 7.08 & 71 \\
0.4 & 0.1 & 7.36 & 94 \\
0.5 & 0.1 & 7.55 & 94 \\
\hline
\end{tabular}

The measurements were carried out with a heating rate of $10^{\circ} \mathrm{C} \mathrm{min}^{-1}$ under flow of $\mathrm{N}_{2}$ gas up to $600^{\circ} \mathrm{C}$. The optical absorption measurements for all thin films were measured in transmittance and absorbance modes with a double beam spectrophotometer (UV-Vis, Spectrophotometer, Spectro Double 8 Auto cell).

2.4. Electrical Properties of the Gas Sensors. The resistivity of gas sensors were measured versus temperature utilizing different gases. The measurements were carried out in the temperature range $20-120^{\circ} \mathrm{C}$ with $\mathrm{O}_{2}, \mathrm{CO}_{2}$, and smoke gas, which reflects the real fire conditions. The effect of $\mathrm{Sb}$ doping on the sensitivity of gas sensor was also studied. All of these measurements have been carried out using home made gas chamber able to work at high temperatures and pressures and under dark conditions to avoid the effect of UV radiation [17]. For the measurement of smoke gas, a white paper was burnt in air then the gas sensor device was exposed to the smoke which composition was given by TGA analyses.

\section{Results and Discussion}

3.1. Effect of TEA on ZnO Nanoparticles. TEA has the chemical formula $\mathrm{N}\left(\mathrm{CH}_{2} \mathrm{CH}_{2} \mathrm{OH}\right)_{3}$, which acts generally as a weak base due to the single lone pair of electrons on nitrogen atom [18]. It is important to understand the physiochemical processes involved in the sol-gel preparation of $\mathrm{ZnO}$ nanoparticles. In an aqueous solution, metal cations $\mathrm{M}^{+Z}$ are solvated by water molecules forming the aquoions as $\left[\mathrm{M}\left(\mathrm{OH}_{2}\right)_{n}\right]^{+Z}$. The $\mathrm{M}-\mathrm{OH}_{2}$ bond is polarized, which facilitates the deprotonation of the coordinated water. In dilute solutions, a range of monomeric species exists such as $\left(\left[\mathrm{M}\left(\mathrm{OH}_{2}\right)_{n-p}(\mathrm{OH})_{p}\right]^{+(z-p)}\right.$ and other hydroxyl species $\left[\mathrm{M}(\mathrm{OH})_{n}\right]$; ultimately oxygen ions are formed. In order to form the poly-nuclear species, which subsequently developed into metal oxide particles, reactions involving condensation must occur [19]. Two important processes have been recognized, which are:

(i) Olation bridge "ol-bridge" formation by reaction of hydroxo and aquo species as follow [20, 21]:

$$
\mathrm{M}-\mathrm{OH}+\mathrm{M}-\mathrm{OH}_{2} \longrightarrow \mathrm{M}-\mathrm{OH}-\mathrm{M}+\mathrm{H}_{2} \mathrm{O}
$$




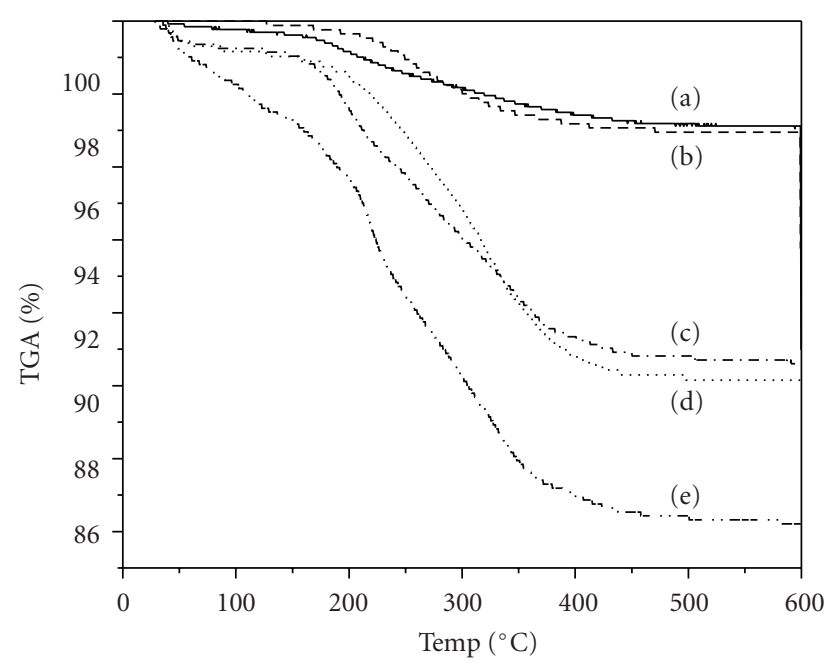

(a) $\mathrm{ZnO}$ with $0.1 \mathrm{M}$ of TEA

(b) $\mathrm{ZnO}$ with $0.2 \mathrm{M}$ of TEA

(c) $\mathrm{ZnO}$ with $0.3 \mathrm{M}$ of TEA

(d) $\mathrm{ZnO}$ with $0.4 \mathrm{M}$ of TEA

(e) $\mathrm{ZnO}$ with $0.5 \mathrm{M}$ of TEA

FIGURE 1: TGA thermograms of $\mathrm{ZnO}$ nanopowders prepared with (a) $0.1 \mathrm{M}$, (b) $0.2 \mathrm{M}$, (c) $0.3 \mathrm{M}$, (d) $0.4 \mathrm{M}$, and (e) $0.5 \mathrm{M}$ TEA.

(ii) Oxolation bridge "oxo-bridge" by the dehydration of hydroxo species:

$$
\mathrm{M}-\mathrm{OH}+\mathrm{HO}-\mathrm{M} \longrightarrow \mathrm{M}-\mathrm{O}-\mathrm{M}+\mathrm{H}_{2} \mathrm{O}
$$

Accordingly, TEA as a complexing agent could coordinate to zinc ions and enhance the dissolution of zinc hydroxide converting its moiety into zinc oxide. As the concentration of TEA increases, the $\mathrm{pH}$ value will increase, Table 1, which will facilitate the solubility of zinc hydroxide and, consequently, $\mathrm{ZnO}$ formation. Table 1 shows also the variation of the net yield of zinc oxide with the concentration of TEA. The $\mathrm{ZnO}$ yield was calculated according to the amount of $\mathrm{Zn}$ in zinc nitrate precursor to that in the resulted $\mathrm{ZnO}$ powder. Also, yield values were calculated after heat treatment of the powder at $400^{\circ} \mathrm{C}$ for 5 minutes to remove any undesirable residue. It is obvious in Table 1 that the yield increases as the $\mathrm{pH}$ value become more basic until it reaches maximum yield of $94 \%$ at $0.5 \mathrm{M}$ TEA. This finding could be easily explained on the basis of lower TEA concentration that means lower complexation with zinc ions in solution, which in turn reduces the probability of converting zinc hydroxide into zinc oxide, giving low yield. In the contrary, higher TEA concentration will be complexed with most of zinc ions, giving more chance for zinc hydroxide to become zinc oxide and finally higher yield [22].

3.2. Thermal Characterization (TGA). The thermal stability of $\mathrm{ZnO}$ nanopowders was evaluated by TGA. The TGA thermograms of $\mathrm{ZnO}$ nanopowders with $0.1,0.2,0.3,0.4$, and $0.5 \mathrm{M}$ of TEA are shown in Figure 1. It is noticeable in Figure 1 at temperature $<100^{\circ} \mathrm{C}$ that weight loss was

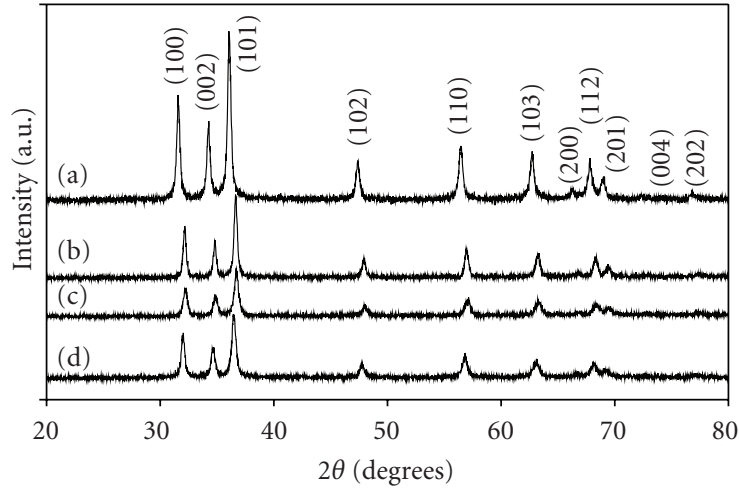

FIGURE 2: XRD patterns of nanocrystalline $\mathrm{ZnO}$ films with (a) $0.1 \mathrm{M}$, (b) $0.2 \mathrm{M}$, (c) $0.3 \mathrm{M}$, and (d) 0.4 M TEA.

equivalent to loss of water being minimum for samples of low TEA content $(0.1$ and $0.2 \mathrm{M})$, while weight loss was more pronounced and reached about $3 \%$ for sample of $0.5 \mathrm{M}$ TEA. Also, the main weight loss temperature ranged between $171.83^{\circ} \mathrm{C}$ and $398.34^{\circ} \mathrm{C}$, and $\mathrm{ZnO}$ yield increased with increasing the concentration of TEA until its maximum value at $0.5 \mathrm{M}$ TEA. The main bulk of these impurities are hydrocarbons substances. Although, $\mathrm{ZnO}$ yield was small at low TEA concentration, there were no impurities, and vice versa at higher TEA contents. This explains the increase in weight loss in the TGA thermographs at higher TEA contents.

3.3. X-Ray Diffraction (XRD). XRD was used to characterize the different phases of the prepared $\mathrm{ZnO}$ nanopowders. Figure 2 shows the XRD patterns for the deposited nanocrystalline $\mathrm{ZnO}$ films with different amounts of TEA. At $0.1 \mathrm{M}$ TEA, the XRD patterns (Figure 2(a)) reveal all peaks of the hexagonal wurtzite crystal structure. Increasing the TEA concentration to $0.2 \mathrm{M}$ (Figure 2(b)), $0.3 \mathrm{M}$ (Figure 2(c)), and $0.4 \mathrm{M}$ (Figure $2(\mathrm{~d})$ ) results in decreasing the peaks intensity and disappearing of some weak peaks (e.g., (200), (004), (202)). Also, the full width half maximum (FWHM) of (101) peak is increased with increasing the TEA concentration, reflecting a decreasing order in particle size of $\mathrm{ZnO}$ with increasing TEA concentration.

Figure 3 demonstrates the XRD patterns of undoped $\mathrm{ZnO}$ nanoparticles and Sb-doped $\mathrm{ZnO}$ with different $\mathrm{wt} \%$ of $\mathrm{Sb}$. All diffraction peaks were indexed to hexagonal wurtzite $\mathrm{ZnO}^{(23)}$. Figure 3(a) reveals a highly crystallized wurtzite structure with no peaks corresponding to $\mathrm{Sb}$. When Sbdoping begins, a very small diffraction peak appeared at $28.8^{\circ}$ (Figure 3(b)), which is increased in intensity with increasing $\mathrm{Sb}$ ratio (Figures 3(c), 3(d), and 3(e)) [23]. This peak is related to $\mathrm{Sb}_{2} \mathrm{O}_{3}$ (JCPDS Card no. 43-1071).

The full width of (002) peak at half-maximum became narrower in all peaks in a single profile. The remarkable difference in the full width at half maximum supports our interpretation that $\mathrm{ZnO}$ crystals may promote along the [001] direction (c-direction), resulting in the formation of nanoparticles [24]. The average crystallite size of $\mathrm{ZnO}$ and $\mathrm{Sb}$-doped $\mathrm{ZnO}$ powders was calculated from the full width 


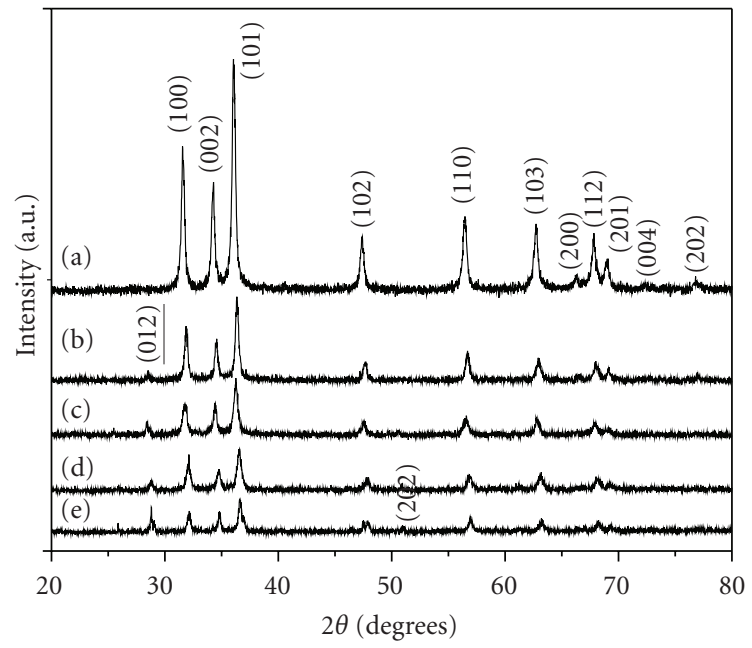

FIGURE 3: XRD pattern of nanoparticles: (a) pure $\mathrm{ZnO}$, (b) $\mathrm{ZnO}: \mathrm{Sb}$ $=97: 3$, (c) $\mathrm{ZnO}: \mathrm{Sb}=95: 5$, (d) $\mathrm{ZnO}: \mathrm{Sb}=93: 7$, and (e) $\mathrm{ZnO}: \mathrm{Sb}=$ 90:10.

TABle 2: EDS of ZnO doped with $3 \mathrm{wt} \% \mathrm{Sb}$.

\begin{tabular}{lcccc}
\hline Element & $(\mathrm{Kev})$ & Mass\% & Error & At\% \\
\hline $\mathrm{O}$ & 0.525 & 17.75 & 0.55 & 47.17 \\
$\mathrm{Zn}$ & 8.630 & 80.08 & 3.00 & 52.07 \\
$\mathrm{Sb}$ & 3.603 & 2.17 & 1.43 & 0.76 \\
\hline Total & & 100.00 & & 100.00 \\
\hline
\end{tabular}

at half maximum of (100) diffraction peak using Debye Scherrer's equation [25]

$$
D=\frac{0.9 \lambda}{B_{2 \theta} \cos \theta_{\max }},
$$

where $D$ is the average crystallite size in $\mathrm{nm}, \lambda$ is the characteristic wavelength of X-ray used (1.5406 $\AA$ ), $\theta$ is the diffraction angle, and $B_{2 \theta}$ is the angular width in radians at intensity equal to half of the maximum peak intensity [26].

The crystallite size of $\mathrm{ZnO}$ is increased from 19 to $28 \mathrm{~nm}$ as TEA concentration increased from 0.1 to $0.5 \mathrm{M}$; respectively. This result indicates that increasing TEA concentration affects $\mathrm{ZnO}$ crystallite size as some undesirable impurities has contributed into the reaction and formed chemical bonds. Smaller particles of $\mathrm{ZnO}$ were successfully fabricated using this simple mixing technique compared with particles prepared using another relatively simple methods such as $\mathrm{ZnO}$-aggregated colloidal spheres obtained using the sol-gel method (average diameter $185 \mathrm{~nm}$ ) [27] or the double-jet method (average diameter $200 \mathrm{~nm}$ ) [28].

3.4. SEM and EDS. Figure 4 shows the SEM images of pure $\mathrm{ZnO}, \mathrm{ZnO}$ doped with $5 \%$, and $10 \% \mathrm{Sb}$, respectively. It is noted that at pure $\mathrm{ZnO}$ (Figure 4(a)), $\mathrm{ZnO}$ particles are well identified and aggregated (100 $\mathrm{nm}$ in size). As $5 \mathrm{wt} \% \mathrm{Sb}$ was added to the reaction (Figure $4(\mathrm{~b})$ ), the particles became smaller and darker, but homogeneous. Even finer particles were observed when wt $\%$ of Sb became 10\% (Figure 4(c))

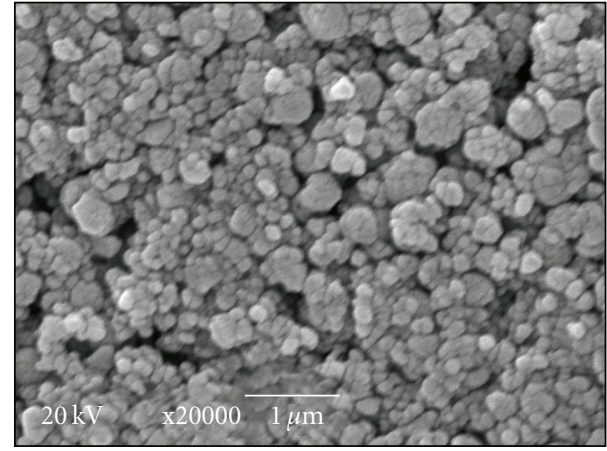

(a)

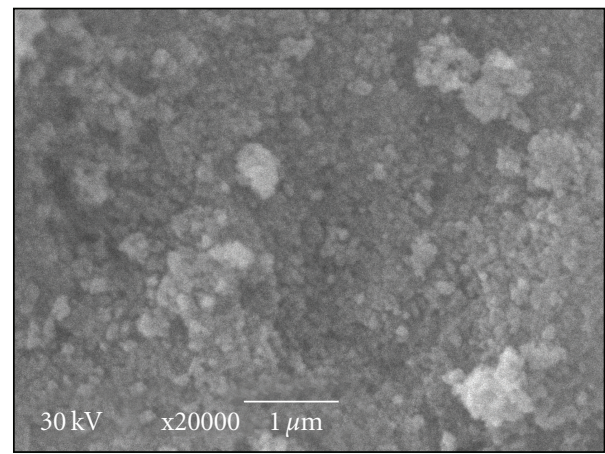

(b)

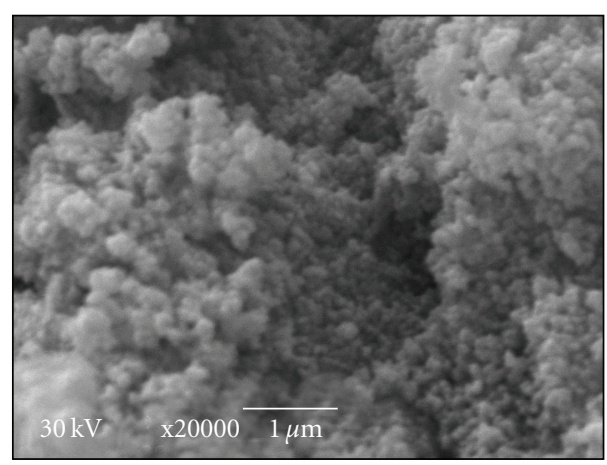

(c)

Figure 4: SEM micrographs of (a) pure $\mathrm{ZnO}$, (b) $\mathrm{ZnO}$ doped with $5 \mathrm{wt} \% \mathrm{Sb}$, and (c) ZnO doped with $10 \mathrm{wt} \% \mathrm{Sb}$.

with distinguished separate dark and light areas or, in other wards, heterogeneous morphology, indicating excess $\mathrm{Sb}$. Figure 5 is the SEM overview of the as-prepared gas sensor, in which the fingers are continuously connected and no isolation points were detected indicating good connection for the $\mathrm{ZnO}$ device gas sensors. Table 2 lists the measured EDS of $\mathrm{Sb}$ wt $\%$ to be $2.17 \%$ for $\mathrm{ZnO}$ nanopowder doped with $3 \mathrm{wt} \% \mathrm{Sb}$. Also, no other impurities were detected indicating pure $\mathrm{ZnO}$ films.

3.5. Transmission Electron Microscopy (TEM). The crystal size and morphology of pure $\mathrm{ZnO}$, and $\mathrm{ZnO}$ doped with 5 and $10 \mathrm{wt} \% \mathrm{Sb}$ were illustrated in Figure 6. The corresponding diffraction patterns are shown in the insets of 


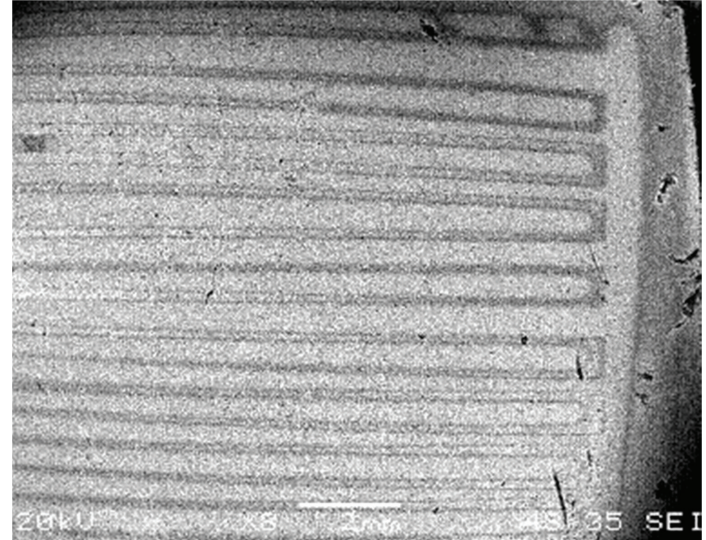

Figure 5: SEM micrograph of the gas sensor consists of $\mathrm{ZnO}$ thick film, heater, and two electrodes.

Figure 6(a). The diffraction patterns illustrate spot patterns of the hexagonal structures of $\mathrm{ZnO}$, designating high crystallinity of $\mathrm{ZnO}$ nanoparticles, which is in good agreements with the XRD data [26]. The particle size of pure $\mathrm{ZnO}$ hexagonal was in the range of $20-30 \mathrm{~nm}$ (Figure 6(a)). However, the doped $\mathrm{ZnO}$ samples have hexagonal particles in the range of 10-20 nm (Figures 6(b) and 6(c)), proving that the doping process reduced the particle size of the former $\mathrm{ZnO}$ particles. These results were compatible with their counterparts of XRD. Furthermore, by comparing the three TEM figures, it is clear that the presence of dark spots of $\mathrm{Sb}$ were increased as its $\mathrm{wt} \%$ increased. In addition, no dark spots were noticed for pure $\mathrm{ZnO}$ (Figure 6(a)), giving rise to homogeneous composition.

\subsection{Fourier Transform Infrared Spectrophotometry (FT-IR).} Figure 7 gives the FTIR spectrum of the $\mathrm{ZnO}$ and $\mathrm{ZnO}$ doped with 5 and $10 \mathrm{wt} \% \mathrm{Sb}$. It is indicated from this figure that for all samples prepared in presence of TEA, the broadband at $3400 \mathrm{~cm}^{-1}$ is assigned for asymmetric and symmetric stretching vibrational $\mathrm{OH}$ groups. However, the band at $1600 \mathrm{~cm}^{-1}$ is assigned for the $\mathrm{H}-\mathrm{O}-\mathrm{H}$ bending vibration. Moreover, the band at $1400 \mathrm{~cm}^{-1}$ stands for $\mathrm{C}-\mathrm{H}_{2}$ in TEA [22]. The IR absorption band at $440 \mathrm{~cm}^{-1}$ originates from the $\mathrm{Zn}-\mathrm{O}$ stretching vibration. Regarding the FT-IR of the $\mathrm{Sb}$ doped samples, a new peak at $688 \mathrm{~cm}^{-1}$ is indicated, which is absent in the spectrum of pure $\mathrm{ZnO}$. This new peak at $688 \mathrm{~cm}^{-1}$ is due to the presence of $\mathrm{Sb}_{2} \mathrm{O}_{3}$ [29] with increasing order in its intensity from $5 \mathrm{wt} \%$ to $10 \mathrm{wt} \% \mathrm{Sb}$ as illustrated in Figure 7.

3.7. UV-Vis Spectroscopy. In this part, we studied the effect of heat treatment and doping on the transmittance and absorbance of $\mathrm{ZnO}$. Figure 8 shows the difference in transmittance between undoped $\mathrm{ZnO}$ and $\mathrm{ZnO}$ films with different $\mathrm{Sb}$ doping ratios. It is clear that the transmittance values are decreased with increasing the amount of $\mathrm{Sb}$ and the transmittance edge is shifted to more UV values.

The absorption coefficients $(\alpha)$ were calculated and plotted for the direct transition $(\alpha h v)^{2}$ versus $h v$ of the

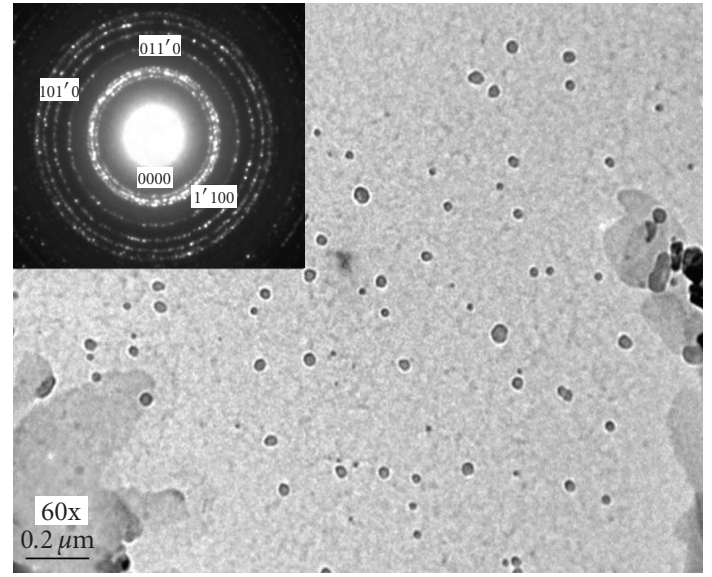

(a)

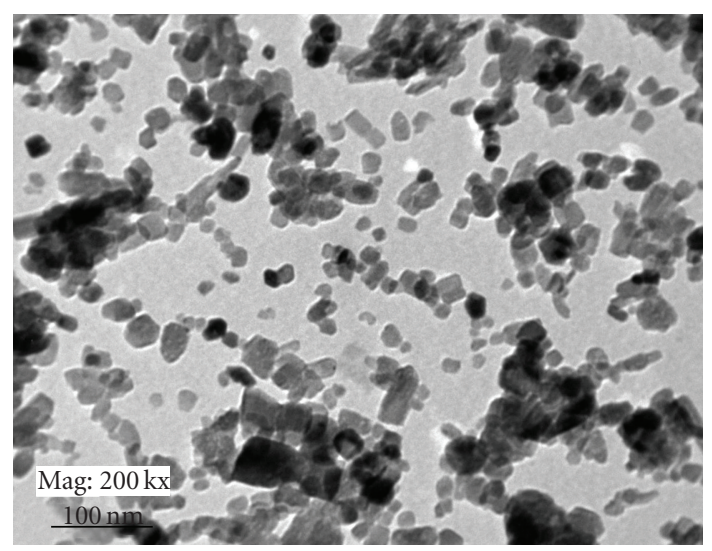

(b)

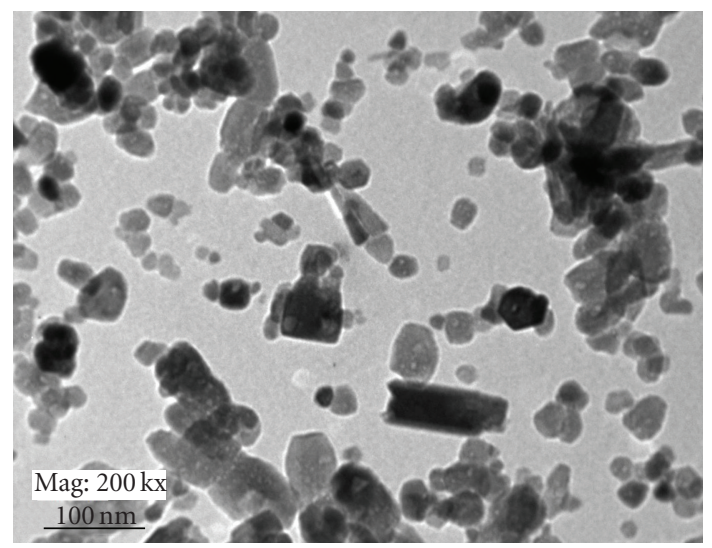

(c)

FIGURE 6: TEM micrographs of (a) pure $\mathrm{ZnO}$, (b) $\mathrm{ZnO}$ doped with $5 \mathrm{wt} \% \mathrm{Sb}$, and (c) $\mathrm{ZnO}$ doped with $10 \mathrm{wt} \% \mathrm{Sb}$.

undoped $\mathrm{ZnO}$ and $\mathrm{ZnO}: \mathrm{Sb}$ films as explained in Figure 9. The value of the band gap of undoped nanocrystalline $\mathrm{ZnO}$ film is $3.26 \mathrm{eV}$ and increased by Sb doping as it was $3.309 \mathrm{eV}$ for $3 \mathrm{wt} \% \mathrm{Sb}, 3.318 \mathrm{eV}$ for $5 \mathrm{wt} \% \mathrm{Sb}$, and $3.329 \mathrm{eV}$ for $10 \mathrm{wt} \% \mathrm{Sb}$. This enhancement in band gap is due to the $\mathrm{Sb}$ incorporation and the high carrier concentration that 


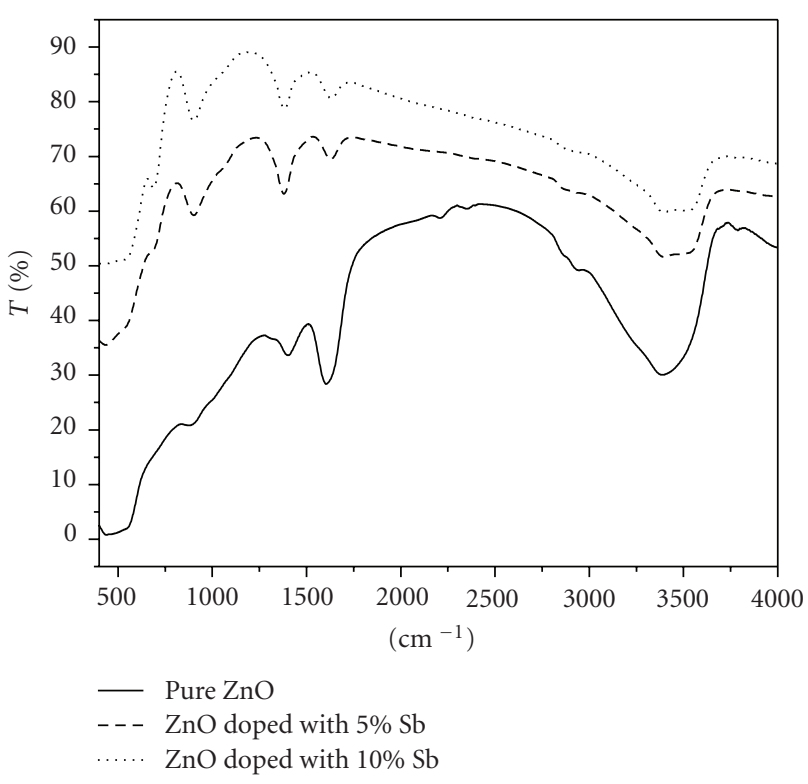

FIGURE 7: FT-IR spectra of (a) pure $\mathrm{ZnO}$, (b) $\mathrm{ZnO}$ doped with $5 \mathrm{wt} \% \mathrm{Sb}$, and (c) ZnO doped with $10 \mathrm{wt} \% \mathrm{Sb}$.

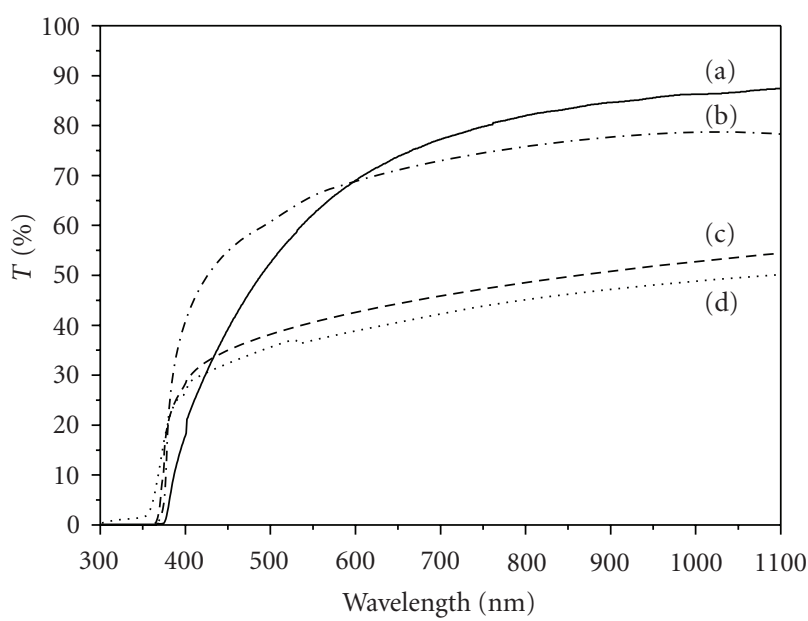

FIGURE 8: UV-Vis transmission spectra of $\mathrm{ZnO}$ thin films: (a) pure, (b) with 3 wt $\%$ Sb, (c) with $5 \mathrm{wt} \% \mathrm{Sb}$, and (d) with $10 \mathrm{wt} \% \mathrm{Sb}$.

moved the optical absorption edge towards lower energy and broadened the energy gap [30].

3.8. Electrical Measurements of Gas Sensors. Solid state gas sensor consists of four main components, isolated substrate (glass, ceramics, etc.), heater, semiconductor metal oxide, and two electrodes. The gas sensitivity, $S$, is given by [31]

$$
S=\frac{R_{a}}{R_{g}},
$$

where $R_{a}$ and $R_{g}$ express the resistance of the sensor in air and in detecting gas, respectively.

Figures 10 and 11 show the gas sensitivity of the gas sensing films made of undoped $\mathrm{ZnO}$ and $\mathrm{Sb}$-doped $\mathrm{ZnO}$ nanoparticles as a function of temperature for $\mathrm{O}_{2}$ and $\mathrm{CO}_{2}$

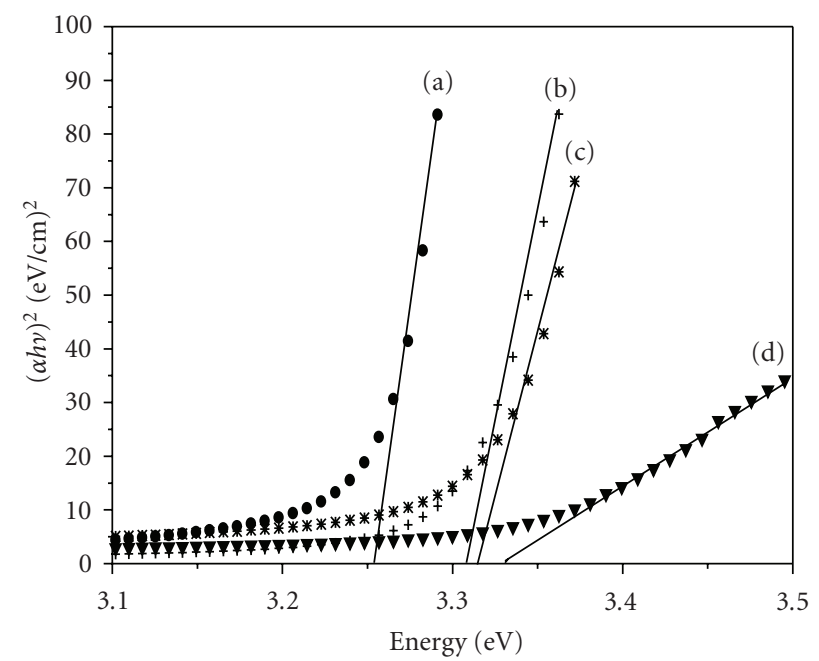

Figure 9: $(\alpha h v)^{2}$ versus energy (eV) for $\mathrm{ZnO}$ films: (a) pure, (b) doped with $3 \mathrm{wt} \% \mathrm{Sb}$, (c) doped with $5 \mathrm{wt} \% \mathrm{Sb}$, and (d) doped with $10 \mathrm{wt} \% \mathrm{Sb}$.

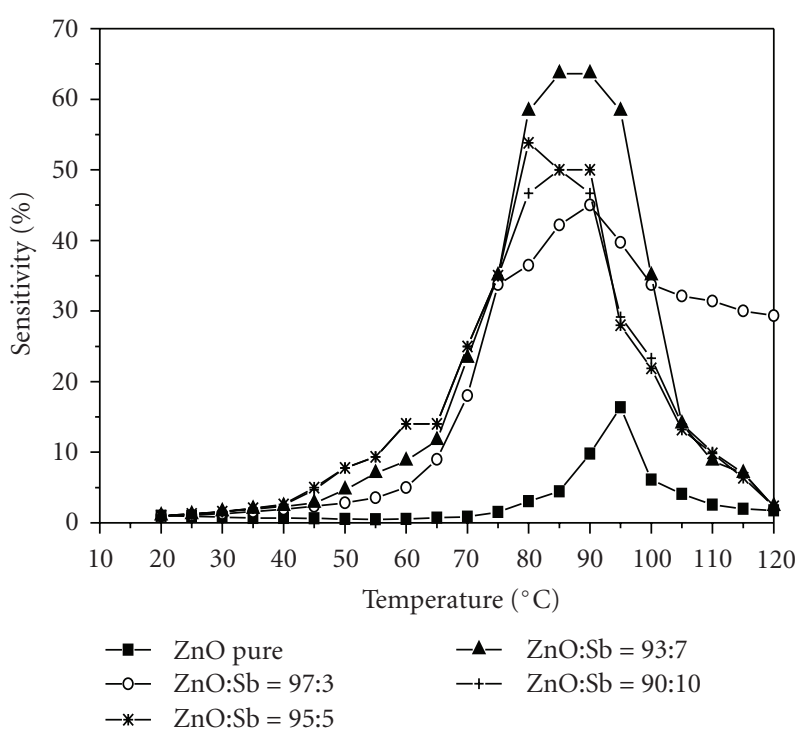

FIGURE 10: Sensitivity of gas sensors towards $\mathrm{O}_{2}$ measured in air as a function of temperature with different doping amounts of $\mathrm{Sb}$.

gases, respectively. From those figures, it is observed that the gas sensitivity is high for $\mathrm{O}_{2}$ gas than $\mathrm{CO}_{2}$. Also, the sensitivity performance towards $\mathrm{O}_{2}$ and $\mathrm{CO}_{2}$ gases of $\mathrm{Sb}$ doped $\mathrm{ZnO}$ nanoparticles is higher than that of pure $\mathrm{ZnO}$. The sensitivity of prepared nanoparticles increased from 15 to $86 \%$ as the $\mathrm{Zn}: \mathrm{Sb}$ weight ratios in the alloy varied from $97: 3$ to $93: 7$ with maximum improvement at $\mathrm{Zn}: \mathrm{Sb}$ = 93:7. Dayan [31] found that $\mathrm{Sb}$ ions dispersed on the surface of the grains of the sensor materials have very low catalytic activity and could easily activate the reducing gases to react with the sensor surface and enhance the sensitivity better than pure $\mathrm{ZnO}$-based sensors. In this case, different form mechanical mixtures in $\mathrm{Sb}$ ions are doped into interstitial or substitutional positions of the $\mathrm{ZnO}$ lattice 


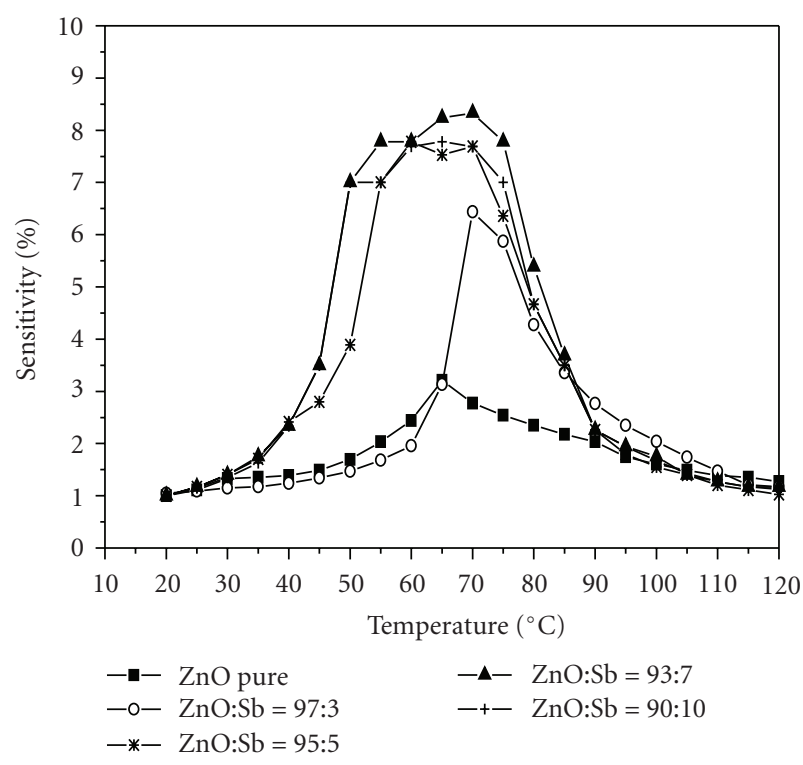

FIGURE 11: Sensitivity of gas sensors towards $\mathrm{CO}_{2}$ measured in air as a function of temperature with different doping amounts of $\mathrm{Sb}$.

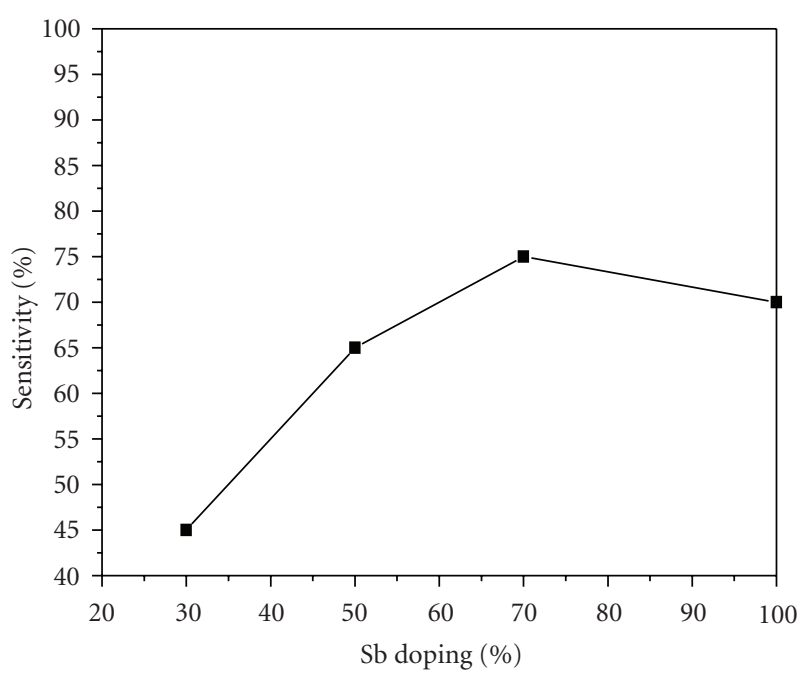

FIGURE 12: Sensitivity of gas sensors towards smoke measured in air as a function of temperature with different doping amounts of Sb.

rather than dispersing onto the grain surface of sensor material. Therefore, $\mathrm{Sb}$ ions of the $\mathrm{ZnO}$ lattice are responsible for the higher gas sensitivity. As the content of $\mathrm{Sb}$ in the sensor device is further increased to become $\mathrm{Zn}: \mathrm{Sb}=90: 10$, the sensitivity of the device dropped down to $75 \%$.

The best use of gas sensor application is the detection of environmental pollutants. One of the most toxic gases that commonly dispersive and has effect on the environment is the smoke gas, which results from combustion of fuels and trashes with a major content of $\mathrm{CO}_{2}$ considering the combustion is full. Figure 12 shows the sensitivity of $\mathrm{ZnO}$ gas sensors doped with different amounts of Sb towards smoke which was analyzed using TGA in air as well as nitrogen and found that the white paper evolves $5 \% \mathrm{H}_{2} \mathrm{O}$ and about $54 \%$ of $\mathrm{CO}_{2}$ of total weight of the sample. As stated before in [28] that $\mathrm{Sb}$ doped $\mathrm{ZnO}$ activates the reducing gases to react with the sensor surface and consequently enhance its sensitivity, which is observed at lower Sb concentrations (3, 5, $7 \mathrm{wt} \%)$. At higher concentration of Sb (10 wt \%), a slightly decrease in the smoke sensitivity (Figure 12), which may be attributed to the decrease in conductivity where transition of electrons is affected by increasing $\mathrm{Sb}^{+5}$ concentration, which is not observed by X-ray diffraction (Figure 3(e)).

\section{Conclusions}

$\mathrm{ZnO}$ and $\mathrm{ZnO}: \mathrm{Sb}$ nanoparticles were prepared by sol-gel technique. Thick films were prepared using spinner coating to construct gas sensor devices. TEA was used as complexing agent and its concentration was greatly affecting the $\mathrm{ZnO}$ yield due to the increase in $\mathrm{pH}$ and the rate of converting zinc hydroxide into oxide. The crystallite size calculated from XRD data ranged 19-28 $\mathrm{nm}$ and almost matched the TEM results. The calculated energy gap was enhanced with $\mathrm{Sb}$ doping due to the high carrier concentration that makes the optical absorption edge moving towards lower energy and broadened the energy gap. The gas sensitivity was higher for $\mathrm{O}_{2}$ gas than $\mathrm{CO}_{2}$, and the sensitivity improved after $\mathrm{Sb}$ doping with maximum enhancement at $\mathrm{Zn}: \mathrm{Sb}=93: 7$.

\section{References}

[1] A. B. Kashyout, M. Soliman, M. El Gamal, and M. Fathy, "Preparation and characterization of nano particles $\mathrm{ZnO}$ films for dye-sensitized solar cells," Materials Chemistry and Physics, vol. 90, no. 2-3, pp. 230-233, 2005.

[2] G. Lu, K. L. Huebner, L. E. Ocola, M. Gajdardziska-Josifovska, and J. Chen, "Gas sensors based on tin oxide nanoparticles synthesized from a mini-arc plasma source," Journal of Nanomaterials, vol. 2006, Article ID 60828, 7 pages, 2006.

[3] M. T. Mohammad and W. A. Abdul Ghafor, "Optical properties of cadmium stannate thin film prepared by pyrolytic process," Solid State Communications, vol. 72, no. 10, pp. 1043-1046, 1989.

[4] M. G. Ambia, M. N. Islam, and M. Obaidul Hakim, "Studies on the seebeck effect in semiconducting $\mathrm{ZnO}$ thin films," Journal of Materials Science, vol. 27, no. 19, pp. 5169-5173, 1992.

[5] W. Shen, Y. Zhao, and C. Zhang, "The preparation of $\mathrm{ZnO}$ based gas-sensing thin films by ink-jet printing method," Thin Solid Films, vol. 483, no. 1-2, pp. 382-387, 2005.

[6] T. Steiner, Semiconductor Nanostructures for Optoelectronic Applications, chapter 6, Barnes \& Noble, 2004.

[7] K.-K. Kim, H.-S. Kim, D.-K. Hwang, J.-H. Lim, and S.-J. Park, "Realization of p-type $\mathrm{ZnO}$ thin films via phosphorus doping and thermal activation of the dopant," Applied Physics Letters, vol. 83, no. 1, pp. 63-65, 2003.

[8] A. K. Srivastava, B. R. Chakraborty, and S. Chandra, "Crystallographically oriented nanorods and nanowires of rfmagetron-sputtered zinc oxide," Journal of Nanomaterials, vol. 2009, Article ID 310360, 2009.

[9] S. J. Pearton, D. P. Norton, K. Ip, Y. W. Heo, and T. Steiner, "Recent progress in processing and properties of $\mathrm{ZnO}$," Superlattices and Microstructures, vol. 34, no. 1-2, pp. 3-32, 2003. 
[10] E. Fortunato, P. Martins, P. Barquinha, et al., "Transparent thin film transistors based on zinc oxide," in Proceedings of the 5th International Conference on Coatings on Glass, p. 887, Saarbucken, Germany, July 2004.

[11] M. Grassi, D. A. W. Soares, A. A. A. De Queiroz, A. H. A. Bressiani, and J. C. Bressiani, "Organometallic chemical vapor deposition of compound semiconductors," Materials Science and Engineering B, vol. 112, no. 2-3, pp. 179-181, 2004.

[12] R. Al Asmar, G. Ferblantier, F. Mailly, P. Gall-Borrut, and A. Foucaran, "Effect of annealing on the electrical and optical properties of electron beam evaporated $\mathrm{ZnO}$ thin films," Thin Solid Films, vol. 473, no. 1, pp. 49-53, 2005.

[13] D. J. Kang, J. S. Kim, S. W. Jeong, Y. Roh, S. H. Jeong, and J. H. Boo, "Structural and electrical characteristics of R.F. magnetron sputtered $\mathrm{ZnO}$ films," Thin Solid Films, vol. 475, no. 1-2, pp. 160-165, 2005.

[14] X. L. Cheng, H. Zhao, L. H. Huo, S. Gao, and J. G. Zhao, "ZnO nanoparticulate thin film: preparation, characterization and gas-sensing property," Sensors and Actuators B, vol. 102, no. 2, pp. 248-252, 2004.

[15] N. M. Sbrockey and S. Genesan, "ZnO thin films by MOCVD," III-Vs Review, vol. 17, no. 7, pp. 23-25, 2004.

[16] E. Filipek and G. Dabrowska, "Unknown thermal properties of $\mathrm{ZnSb}_{2} \mathrm{O}_{6}$ and $\mathrm{Zn}_{7} \mathrm{Sb}_{2} \mathrm{O}_{12}$ compounds: reactivity of $\alpha-\mathrm{Sb}_{2} \mathrm{O}_{4}$ with $\mathrm{ZnO}$ on heating in air," Journal of Thermal Analysis and Calorimetry, vol. 94, no. 1, pp. 195-201, 2008.

[17] R. Martins, E. Fortunato, P. Nunes et al., "Zinc oxide as an ozone sensor," Journal of Applied Physics, vol. 96, no. 3, pp. 1398-1408, 2004.

[18] Technical Bulletin, Huntsman Corporation, Triethanolamine99\%, (CAS 102-71-6).

[19] K. Govender, D. S. Boyle, P. B. Kenway, and P. O'Brien, "Understanding the factors that govern the deposition and morphology of thin films of $\mathrm{ZnO}$ from aqueous solution?" Journal of Materials Chemistry, vol. 14, no. 16, pp. 2575-2591, 2004.

[20] G. Bohnsack and B. Bunsen-Ges, "The spectrophotometric determination of hydrolysis constants of mononuclear ions of zinc," Physical Chemistry, vol. 92, no. 9, pp. 803-807, 1988.

[21] T. Trindade, J. D. Pedrosa De Jesus, and P. O’Brien, "Preparation of zinc oxide and zinc sulfide powders by controlled precipitation from aqueous solution," Journal of Materials Chemistry, vol. 4, no. 10, pp. 1611-1617, 1994.

[22] D. W. Zeng, C. S. Xie, B. L. Zhu et al., "Controlled growth of ZnO nanomaterials via doping Sb," Journal of Crystal Growth, vol. 266, no. 4, pp. 511-518, 2004.

[23] T.-J. Hsueh and C.-L. Hsu, "Fabrication of gas sensing devices with $\mathrm{ZnO}$ nanostructure by the low-temperature oxidation of zinc particles," Sensors and Actuators B, vol. 131, no. 2, pp. 572-576, 2008.

[24] M. C. Carotta, A. Cervi, V. di Natale et al., "ZnO gas sensors: a comparison between nanoparticles and nanotetrapods-based thick films," Sensors and Actuators B, vol. 137, no. 1, pp. 164 $169,2009$.

[25] D. Gruber, F. Kraus, and J. Müller, "A novel gas sensor design based on $\mathrm{CH}_{4} / \mathrm{H}_{2} / \mathrm{H}_{2} \mathrm{O}$ plasma etched $\mathrm{ZnO}$ thin films," Sensors and Actuators B, vol. 92, no. 1-2, pp. 81-89, 2003.

[26] Q. Zhong and E. Matijević, "Preparation of uniform zinc oxide colloids by controlled double-jet precipitation," Journal of Materials Chemistry, vol. 6, no. 3, pp. 443-447, 1996.

[27] C. Liewhiran and S. Phanichphant, "Influence of thickness on ethanol sensing characteristics of doctor-bladed thick film from flame-made $\mathrm{ZnO}$ nanoparticles," Sensors, vol. 7, no. 2, pp. 185-201, 2007.
[28] Y.-J. Chen, C.-L. Zhu, and G. Xiao, "Ethanol sensing characteristics of ambient temperature sonochemically synthesized $\mathrm{ZnO}$ nanotubes," Sensors and Actuators B, vol. 129, no. 2, pp. 639-642, 2008.

[29] M. Nalin, Y. Messaddeq, S. J. L. Ribeiro et al., "Structural organization and thermal properties of the $\mathrm{Sb}_{2} \mathrm{O}_{3}-\mathrm{SbPO}_{4}$ glass system," Journal of Materials Chemistry, vol. 14, no. 23, pp. 3398-3405, 2004.

[30] F.-C. Zhang, Z.-Y. Zhang, W.-H. Zhang, J.-F. Yan, and J.-N. Yun, "First-principles calculation of electronic structure and optical properties of Sb-doped ZnO," Chinese Physics Letters, vol. 25, no. 10, pp. 3735-3738, 2008.

[31] N. J. Dayan, S. R. Sainkar, R. N. Karekar, and R. C. Aiyer, "Formulation and characterization of $\mathrm{ZnO}: \mathrm{Sb}$ thick-film gas sensors," Thin Solid Films, vol. 325, no. 1-2, pp. 254-258, 1998. 

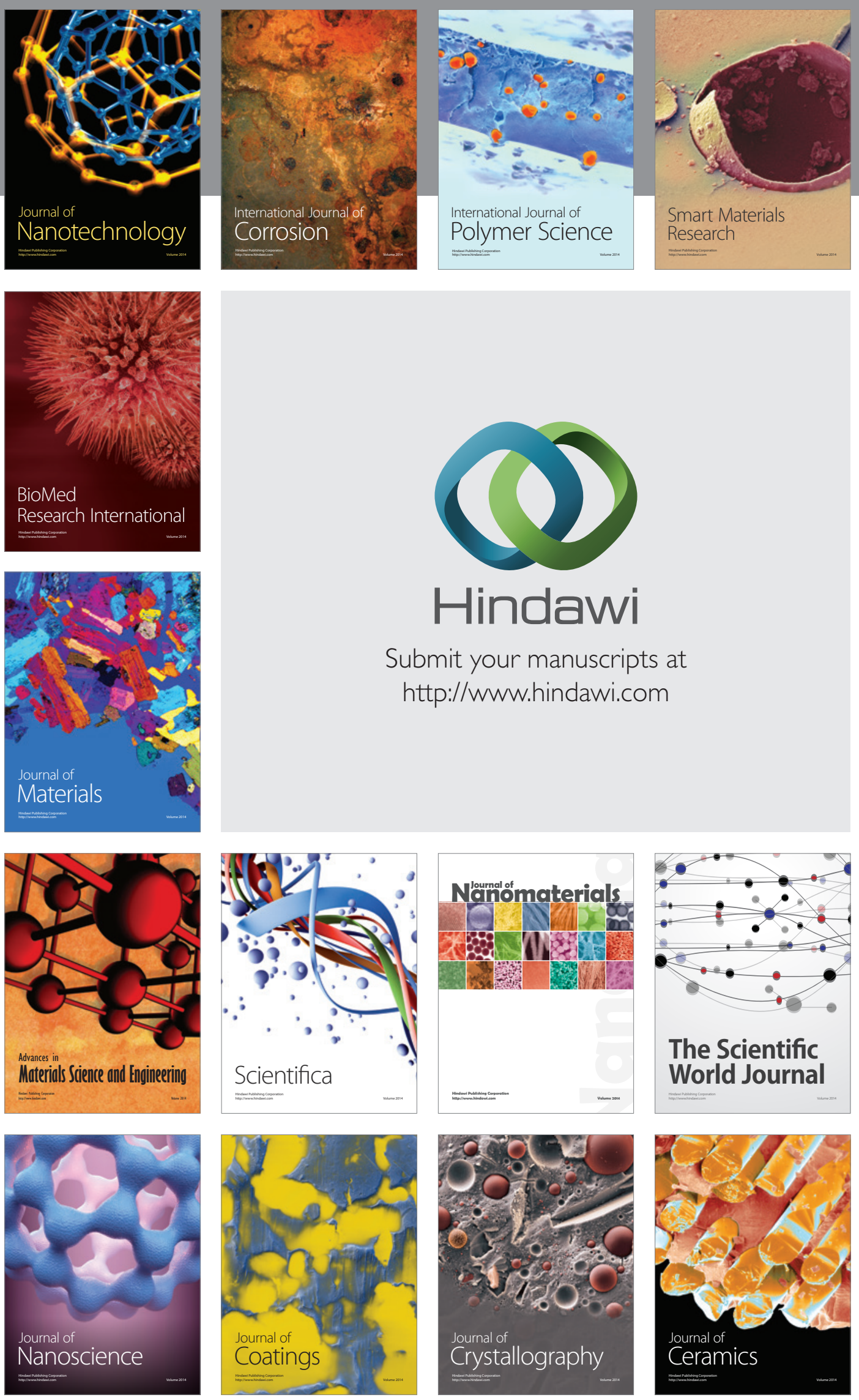

The Scientific World Journal

Submit your manuscripts at

http://www.hindawi.com

\section{World Journal}

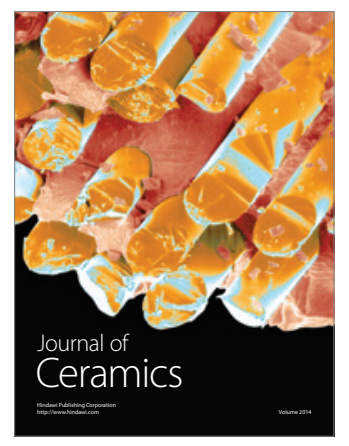

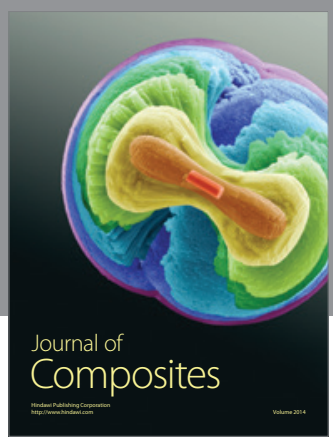
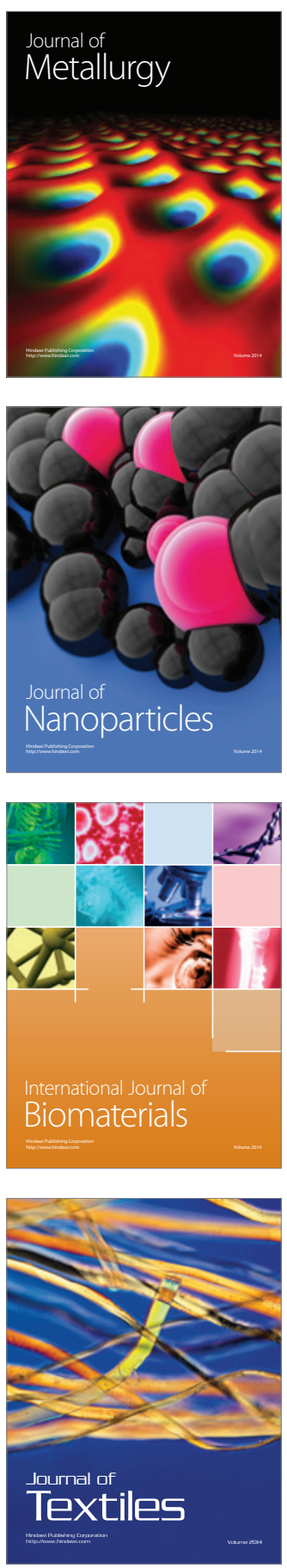